\title{
OPTIMALISASI KUALITAS PEMBELAJARAN BAHASA INDONESIA MELALUI PENERAPAN MODEL PEMBELAJARAN BERBASIS SIKLUS DENGAN DISTRIBUSI PERMASALAHAN KONTEKSTUAL
}

\author{
Oleh \\ Ni Wayan Sudarti \\ IKIP PGRI Bali \\ wayan.sudarti.yanti@gmail.com
}

Diterima 05 Januari 2017, direvisi 30 Pebruari 2017, diterbitkan 31 Agustus 2017

\begin{abstract}
This study aims to: (1) to determine the effectiveness of the model-based learning cycle by providing contextual problems can motivate learning Indonesian in class X MMI SMK Negeri 1 Sukawati, (2) to identify any obstacles obtained in the application-based learning model cycle with the provision of contextual issues, in class X MM1 SMK Negeri 1 Sukawati. This research uses descriptive qualitative data analysis and classroom action research (PTK). This research method using two cycles, each cycle consisting of planning, action, observation and reflection stages.

The data is the data analyzed motivation and learning outcomes. Broadly speaking, the average percentage of the observation of motivation $70.2 \%$ in the first cycle increased to $80.2 \%$ in the second cycle means an increase of $10 \%$ in the second cycle. While based on the analysis of student questionnaire presentation success action diproleh $76.1 \%$ in the first cycle increased to 78.84 in the second cycle, means an increase of $2.74 \%$ in the second cycle. Judging from individual mastery, the first cycle reaches $81 \%$ means that students who obtain above or equal to 75, as many as 26 out of 32 students, the remaining 6 students, or $18 \%$ incomplete. While on the second cycle, the percentage of individual mastery has been increased, the second cycle of individual completeness reached $93.8 \%$ means that students who received grades above or equal to 75, as many as 30 people and 2 students or $6.25 \%$ of students have not been completed. This means an increase of individual mastery of the first cycle to the second cycle of $11.75 \%$ or 4 students. For classical completeness on the first cycle is $81 \%$ increased to $93.8 \%$ in the second cycle, meaning an increase by $12.8 \%$ in the second cycle.
\end{abstract}


From this study it can be concluded that: (1) The application of the modelbased learning cycle by providing contextual problems can increase students' motivation class X MMI SMK Negeri 1 Sukawati, with the material of the Indonesian language discourse. This can be seen in the increase in the observation of students $70.2 \%$ in the first cycle and increased to $80.2 \%$ in the second cycle. (2) Barriers acquired in the application of learning models berbasisis cycle in class X MMI SMK Negeri 1 Sukawati, can be solved, it is evident from the results achieved in the classical completeness, ie $81 \%$ in the first cycle, increased to $93.8 \%$ in the second cycle.

\section{Keywords: Cycle Model Based Learning, Language Learning Motivation Indonesian}

\section{PENDAHULUAN}

Bahasa Indonesia merupakan alat komunikasi untuk menyampaikan ide atau gagasan baik lisan maupun tulisan. Bahasa Indonesia adalah mata pelajaran yang wajib diberikan dari jenjang sekolah dasar sampai dengan perguruan tinggi. Hal itu, karena bahasa Indonesia merupakan bahasa nasional sekaligus bahasa negara di Indonesia. Bahasa Indonesia dikatakan baik jika mudah dimengerti, mudah dipahami, serta dapat diterima oleh pemakai bahasa itu sendiri. Sedangkan bahasa Indonesia yang benar jika bahasa itu sesuai dengan kaidah-kaidah atau aturan-aturan yang berlaku. Untuk tetap berkembangnya bahasa Indonesia di masyarakat, sebagai pemakai bahasa tidak boleh tinggal diam terhadap perkembangan bahasa khususnya dalam aspek linguistik sebagai salah satu bagian yang integral.

Pada tataran ideal, pengajaran bahasa Indonesia diharapkan menjadi ujung tombak pembentukan karakter bangsa. Pengajaran bahasa Indonesia diharapkam dapat menanamkan serta menumbuh kembangkan citra budaya yang santun, etis, dan menjungjung tinggi nilai humaniora sehingga menyempurnakan manusia sesuai hakikatnya. Harapan yang ideal ini tampaknya sulit diwujudkan karena motivasi belajar bahasa Indonesia siswa relatif rendah. Untuk itu perlu ada upaya nyata untuk menanggulangi persoalan ini.
Untuk itu perlu ada upaya pembaharuan strategi pembelajaran bahasa Indonesia yang lebih konprehensif dan bermakna. Tujuan pembelajaran bahasa Indonesia dari tingkat pendidikan dasar hingga menengah adalah untuk meningkatkan ketrampilan berbahasa para siswa. Ketrampilan berbahasa Indonesia akan dapat terwujud apabila didukung oleh pengetahuan, ketrampilan, dan sikap dalam mempelajari bahasa dan sastra Indonesia. Berdasarkan haltersebut, secara sederhana dapat dikatakan standar kompetensi pembelajaran bahasa Indonesia adalah siswa memiliki pengetahuan, ketrampilan, dan sikap positif terhadap bahasa dan sastra Indonesia. Ini berarti paradigma pengajaran bergeser ke arah murid dengan tetap mempertahankan tanggung jawab dan otoritas guru bahasa Indonesia. Pembelajaran ini diharapkan dapat mengembangkan komunikasi komunikatif pada setiap individu siswa. Paradigma pembelajaran ini sering disebut SCL (Student Centred Learning). Dalam konteks pembelajaran ini guru dan murid berperan sebagai subjek belajar dalam peran yang berbeda. Guru lebih berfungsi sebagai fasilitator dan motivator.

Akan tetapi dari uraian di atas ternyata di kelas MM1 SMK Negeri 1 Sukawati belum mencapai target ketutasan minimal yang telah ditetapkan oleh pihak sekolah. Untuk pembelajaran bahasa Indonesia ketuntasan 
minimalnya secara individual adalah 75 dan hasil secara klasikal adalah 75, dari data hasil analisis pre test, siswa yang mendapat nilai 75 keatas sebanyak 24 orang dari 32 siswa, ini berarti ketuntasan klasikal baru mencapai 59\% yang artinya secara klasikal belum tuntas. Berdasarkan data di atas maka peneliti berasumsi bahwa hal ini disebabkan karena proses pembelajaran belum optimal. Dimana guru dalam mengajar masih berorientasi pada target materi, sehingga proses pembelajaran masih berpusat pada guru (teacher centered learning).

Akibatnya siswa kurang dapat berkreativitas, selain itu berdasarkan hasil pengamatan secara langsung ke dalam kelas oleh peneliti pada siswa kelas MM1 SMK Negeri 1 Sukawati, menunjukkan motivasi siswa masih rendah. Hal ini terlihat saat diskusi siswa cendrung diam dan perhatian siswa tidak terfokus pada materi. Pada kegiatan awal sampai kegiatan inti masih ada siswa bermainmain dan berbincang-bincang dengan masalah di luar materi pembelajaran. Hal ini berarti metode pelajaran yang diterapkan kurang bervariatif atau hanya dengan satu atau dua metode saja, sehingga siswa tidak termotivasi.

Dari uraian di atas melalui kesempatan ini, peneliti memberikan alternatif pemecahan, yaitu dengan menerapkan model pembelajaran berbasis siklus (cycle learning) dengan pemberian masalah kontekstual. Model pembelajaran ini sangat efektip karena mendorong siswa mau belajar mandiri. Model pembelajaran ini menjadi pilihan, karena mempunyai beberapa kelebihan jika dibandingkan dengan model lain. Pembelajaran berbasis siklus adalah model pembelajaran yang berpusat pada siswa (student centered learning). Model pembelajaran berbasis siklus merupakan rangkaian proses pembelajaran yang memiliki tahap-tahap (fase) yang diorganisasi sedemikian rupa sehingga siswa dapat menguasai kompetensi-kompetensi yang harus dikuasai, dengan berperan aktif dalam proses pembelajaran. Implementasi model pembelajaran berbasis siklus dalam proses pembelajaran menempatkan guru sebagai fasilitator yang menglola langsung proses pembelajaran, mulai dari perencanaan (terutama pengembangan prangkat pembelajaran), pelaksanaan (terutama pemberian pertanyaan, arahan dan proses bimbingan) sampai fase evaluasi. Efektifitas implementasi dari model pembelajaran inidapat diukur melalui observasi proses dan pemberian tes. Jika ternyata hasil dan motifasi hasil belajar siswa belum memuaskan, maka dapat dilakukan siklus berikutnya, yang pelaksanaanya harus lebih baik dari siklus sebelumnya dengan cara mengantisifasi kelemahan-kelemahan siklus sebelumnya, sampai hasilnya memuaskan.

Menurut Lorsbach, (Fajaroh dan Dasma, 2007) pembelajaran dengan menggunakan model pembelajaran berbasis siklus, ada lima fase atau tahapan yang harus dilalui, yaitu: (1) engagement (pemusatan perhatian), (2) exploration (eksplorasi), (3) ekplanation (penjelasan), (4) elaboration (aplikasi), (5) dan evaluation (evaluasi). Kelebihan yang lain adalah kalau peserta didik dihadapkan pada suatu masalah yang nyata, yang dihadapi dalam kehidupan sehari-hari, maka mereka akan termotivasi dan pada akhirnya mereka bukan hanya akan memecahkan masalah tetapi mereka belajar sesuatu yang baru. Pemberian masalah yang kontekstual memegang peranan yang sangat penting dalam pembelajaran bahasa Indonesia, terutama dalam proses penerapannya sehari-hari. Strategi pembelajaran ini sangat efektif untuk mengajarkan proses berfikir tingkat tinggi, membantu siswa memproses informasi yang telah dimilikinya dan membantu siswa belajar bekerja sama dan melatih ketrampilan sosial lainnya. Strategi pembelajaran pemberian masalah kontekstual bertumpu pada psikologi, kognitif dan pandangan konstruktivisme mengenai belajar, penulis mempunyai keyakinan jika model pembelajaran ini mampu mengatasi 
masalah yang sedang dihadapi, walau dalam penerapannya tentu saja akan menemukan hambatan-hambatan yang harus di selesaikan karena tidak ada satu metode yang sempurna, yang penulis harapkan bisa di pecahkan dengan penerapan model pembelajaran berbasis siklus dengan pemberian masalah kontekstual.

Belajar adalah proses berfikir, belajar berfikir menekankan kepada proses mencari dan menemukan pengetahuan melalui interaksi antara individu dengan lingkungan. Dalam hal ini proses pendidikan disekolah tidak hanya menekankan kepada akumulasi pengetahuan materi pelajaran,tetapi yang diutamakan adalah kemampuan siswa untuk memproleh kemampuan sendiri (self regulated). Asumsi yang mendasari pembelajaran berfikir adalah bahwa pengetahuan itu tidak datang dari luar, akan tetapi dibentuk oleh individu itu sendiri dalam struktur kognitif yang dimilikinya. Atas dasar asumsi itulah pembelajaran berfikir memandang bahwa mengajar itu bukanlah memindahkan pengetahuan dari guru pada siswa, melainkan suatu aktivitas yang memungkinkan siswa dapat membangun sendiri pengetahuannya.

\section{PEMBAHASAN}

\subsection{Motivasi Belajar Siswa.}

Motivasi belajar siswa diamati dari tiga aspek yang meliputi:

1. Aspek kognitif, yang terdiri dari tiga indikator antara lain; (a) menjawab pertanyaan dari guru atau siswa lain, (b) mengajukan pertanyaan yang berkaitan dengan materi yang dibahas, (c) mengemukakan ide-ide.

2. Aspek tingkah laku, yang terdiri dari lima indikator antara lain; (a) aktif dalam diskusi selama proses pembelajaran, (b) cendrung mendominasi saat kegiatan pembelajaran, (c) melaporkan hasil kerja kelompok tanpa ditunjuk, (d) memperbaiki jawaban yang keliru dengan segera, (e) mencatat apa yang telah dipelajari.

3. Aspek ketertarikan, yang terdiri dari tiga indikator antara lain; (a) menunjukkan sikap ingin tau, (b) berusaha untuk menyelesaikan tugas yang dibebankan oleh guru, (c) mau berfikir dan tidak putus asa dalam mencari jawaban.

Data ini diambil selama proses pembelajaran berlangsung dan dicatat dalam lembar observasi motivasi belajar siswa, dan juga melalui sebaran angket yang diisi oleh siswa saat pembelajaran berakhir.

Tindakan yang diberikan pada siklus I dan siklus II menjadi penentu dalam peningkatan motivasi belajar dari siklus I ke siklus II. Secara garis besar rata-rata hasil observasi motivasi $70,2 \%$ pada siklus I meningkat menjadi $80,2 \%$ pada siklus II. Sehingga dapat dikatakan ada peningkatan sebesar $10 \%$. Kemudian berdasarkan analisis angket siswa, diproleh presentase keberhasilan tindakan $76,1 \%$ pada siklus I meningkat menjadi $78,84 \%$ pada siklus II, berarti terjadi peningkatan sebesar 2,74\% pada analisis angket siswa yang dilaksanakan.

Secara rinci peningkatan-peningkatan presentase tiap-tiap aspek adalah sebagai berikut. Peningkatan tertinggi terjadi pada aspek tingkah laku, yaitu 91,9\% pada siklus I meningkat menjadi $93,5 \%$ pada siklus II, berarti terjadi peningkatan sebesar 1,6\%. Kemudian aspek kognitif, yaitu 46,9\% pada siklus I meningkat menjadi $62,6 \%$ pada siklus II, berarti terjadi peningkatan sebesar $15,7 \%$. Dan yang terakhir adalah aspek ketertarikan persentase keberhasilannya $71,9 \%$ pada siklus I meningkat menjadi $87,5 \%$ pada siklus II, berarti terjadi peningkatan sebesar 15,6\% .

Berdasarkan refleksi pada siklus I dan II, keberhasilan peningkatan motivasi belajar siswa, merupakan efek dari kegiatan pembelajaran yang digunakan. Adanya perbaikan-perbaikan pembelajaran pada siklus 
II, memberikan efek positif pada peningkatan motivasi belajar siswa.

Jadi dari urain tentang hasil observasi motivasi siswa tersebut terlihat bahwa proses pembelajaran dengan model pembelajaran berbasis siklus (cycle learning) melalui pemberian masalah kontekstual, dapat meningkatkan motivasi belajar siswa.

\subsection{Hasil Belajar Siswa.}

Hasil belajar adalah kemampuankemampuan yang dimiliki siswa setelah ia menerima pengalaman belajarnya, Sudjana (2008;22). Hasil belajar yang dimaksud pada penelitin ini adalah hasil belajar ranah kognitif siswa, yang diukur melalui tes akhir berupa ulangan harian. Peningkatan hasil belajar dapat dilihat dari tes formatif siklus I yang dibandingkan pada tes formatif siklus II, serta membandingkan pula dengan ketuntasan belajar yang diproleh oleh siswa baik secara individual maupun secara klasikal pada siklus I maupun siklus II.

Pada penelitian ini siswa yang dinilai hasil tesnya sebanyak 32 orang siswa, yang dimana selama proses pembelajaran mengikuti pelajaran dengan baik pada siklus I maupun siklus II.

Dari hasil analisis data hasil belajar siswa terlihat bahwa, pada siklus I memproleh nilai rata-rata $78,3 \%$ pada akhir siklus II telah meningkat menjadi $82,9 \%$ brararti nilai ratarata kelas mengalami peningkatan sebesar 4,6 poin. Ditinjau dari ketuntasan individual, pada siklus I baru mencapai $81 \%$ artinya siswa yang memproleh nilai diatas atau sama dengan 75 , sebanyak 26 orang dari 32 orang siswa. Sisanya yaitu $18 \%$ belum tuntas, atau 6 orang mendapatkan nilai dibawah 75. Sedangkan pada siklus II, presentase ketuntasan individualnya telah mengalami peningkatkan, pada siklus II ketuntasan individualnya mencapai $93,8 \%$ artinya siswa yang memperoleh nilai diatas atau sama dengan 75 , sebanyak 30 orang dan 2 orang atau 6,25\% siswa memperoleh nilai dibawah 75 , atau yang dinyatakan belum tuntas. Ini berarti peningkatan ketuntasan indvidual dari siklus I ke siklus II, sebesar $11,75 \%$ atau 4 orang siswa. Untuk ketuntasan klasikal juga mengalami peningkatan, ketuntasan klasikal pada sklus I adalah $81 \%$, meningkat menjadi $93,8 \%$ jadi peningkatanya yaitu $12,8 \%$.

Dengan model pembelajaran berbasis siklus melalui pemberian masalah kontekstual dapat meningkatkan motivasi dan hasil belajar siswa. Pembelajaran berbasis siklus mempunyai keunggulan:

1. Meningkatkan motivasi belajar karena siswa dilibatkan secara aktif dalam proses pembelajaran.

2. Membantu mengembangkan sikap ilmiah.

3. Pembelajaran lebih bermakna.

\subsection{Hasil Observasi Proses Pembelajaran.}

Dari hasil pengamatan tentang pelaksanaan pembelajaran, ternyata hambatan yang diproleh, (1) pada siklus I, peneliti belum menampakkan ke lima fase langkah-langkah pembelajaran cycle learning. Ini berarti peneliti belum benar-benar memahami keterlaksanaan model pembelajaran cycle learning. Pada siklus II peneliti sudah dapat mengatasi hambatan tersebut dengan melihat kekurangan yang ada dalam data observasi dengan meningkatkan pengetahuan tentang cycle learning dan penerapannya dalam pembelajaran. (2) pada siklus I, aspek kognitif nilai rata-rata yang diperoleh masih dalam katagori kurang, namun pada siklus II, sudah mencapai katagori baik. (3) ketuntasan secara individual pada siklus I siswa yang belum tuntas sebanyak 6 orang, namun pada siklus II menjadi 2 orang siswa, berarti terjadi peningkatan sebanyak 4 orang siswa. 


\section{SIMPULAN.}

Berdasarkan hasil penelitian yang dilaksanakan di SMK Negeri 1 Sukawati, dapat disimpulkan bahwa : .

1. Penerapan model pembelajaran berbasis siklus dengan pemberian masalah kontekstual dapat meningkatkan motivasi belajar siswa kelas X MM1 SMK Negeri 1 Sukawati, dengan materi wacana bahasa Indonesia. Hal ini dapat terlihat pada peningkatan hasil observasi siswa $70,2 \%$ pada siklus I dan meningkat menjadi $80,2 \%$ pada siklus II.

2. Hambatan-hambatan yang didapatan dalam penerapan model pembelajaran berbasis siklus di kelas X MM1 SMK Negeri 1 Sukawati, pada siklus I sudah dapat diatasai dengan penerapan model pembelajaran berbasis siklus pada siklus II, itu terbukti dari ketuntasan yang dicapai secara klasikal, yaitu mencapai $81 \%$ pada siklus I meningkat menjadi $93,8 \%$ pada siklus II.

\section{DAFTAR PUSTAKA}

Arikunto. (2006). Penelitian Tindakan Kelas. Jakarta: Bumi Aksara.

Darmayani S. (1992). Penuntun Belajaryang Sukses. Jakarta; Nina Karya Jaya.

Djamarah. (1995). Strategi Belajar Mengajar. Jakarta ; Rineka Cipta.

Hamsah. (2006). Perencanaan Pembelajaran. Jakarta ; Bumi Aksaara.

Lie, Anita. (2002). Cooperative Learning, Jakarta : Graznido.

Lorsbach. (2007). Strategi Belajar Mengajar. Jakarta; Rineka Cipta.

Mulyasa, E. (2007). Menjadi Guru Profesional. Bandung; Rosda Karya.

Sugiyono. (1994). Statistika untuk Penelitian. Bandung; Alfhabeta.

Suharsimi, Arikunto. (2006). Prosudur Penelitian Suatu Pendekatan Praktek. Jakarta : Rineka Cipta.

Sujana. (1997). Penilaian Hasil proses Belajar Mengajar. Bandung; Rosda Karya

Trianto. (2007). Model pembelajaran. Bandung; Prestasi Pustaka.

Waras Kamandi, dkk. (2007). Model-model Pembelajaran Inovatif,Malang; UM Press. 